\title{
Faktor Kejadian Anemia pada Pasien Kanker yang Mendapat Radioterapi dan atau Kemoterapi
}

\section{Factors of Anemia in Cancer Patients Getting Radiotherapy and/or Chemotherapy}

\author{
Alpha Olivia Hidayati ${ }^{1}$, Siti Arifah ${ }^{2}$ \\ Program Studi D3 Radiologi STIKES Guna Bangsa Yogyakarta, Indonesia
}

\section{ARTICLE INFO}

\section{Article history: \\ Received date \\ 15 Nov 2019 \\ Revised date \\ 26 Feb 2020 \\ Accepted date \\ 24 Apr 2020}

\section{Keywords:}

Anemia;

Cancer history;

Nutrient intake;

Radiotherapy;

Therapy history.

\section{Kata kunci:}

Anemia;

Riwayat kanker;

Asupan zat gizi;

Radioterapi;

Riwayat terapi.

\author{
ABSTRACT/ ABSTRAK
}

Base on research, radiotherapy can reduce cancer recurrence in 10 years from $35 \%$ to $19,3 \%$ in breast cancer. However, the therapy given affects the life quality of patients, one of which is anemia. Anemia causes a decrease in response and tolerance to treatment. This study aims to determine the factors associated with the incidence of anemia in cancer patients who receive radiotherapy and or chemotherapy. This study was an observational analytic study with a cross-sectional design. The method of sampling with consecutive sampling with a minimum sample size of 47 . The result showed the age of a $p$-value $(0,321)>0,05$, the number of fractions a $p$-value $(0,181)>0.05$, the frequency of light that had been conducted a $p$-value $(0,160)>0,05$, type of radiotherapy a $p$ value $(0,933)>0,05$, setting radiotherapy a $p$-value $(0,769)>0,05$, history of blood transfusion during chemotherapy a $p$-value $(0,411)>0,05$ and nutrient intake (Protein a $p$ value $(0,337)>0.05$, iron a $p$-value $(0,086)>0,05$, zinc a $p$-value $(0,411)>0,05$, folic acid a $p$-value $(0,963)>0,05$, vitamin $\mathrm{C}$ a $p$-value $(0,240)>0,05)$. Meanwhile, the total radiation dose received by respondents during one period of radiotherapy showed that there was a relationship with the incidence of anemia with a $p$-value $(0,045)<0,05$. As conclusions, that there was no significant relationship between age, type of cancer, number of fractions, frequency of light that had been conducted, type of radiotherapy, radiotherapy settings, history of blood transfusion during chemotherapy and nutrient intake, while the total radiation dose given to respondents showed a significant relationship with anemia incidence.

Berdasarkan penelitian, radioterapi dapat menurunkan rekurensi kanker dalam 10 tahun dari 35\% menjadi 19,3\% pada kanker payudara. Namun demikian, terapi yang diberikan dapat berpengaruh pada kualitas hidup pasien, salah satunya terjadinya anemia. Anemia dapat menyebabkan penurunan respon dan toleransi terhadap pengobatan. Penelitian ini bertujuan untuk mengetahui faktor - faktor yang berhubungan dengan kejadian anemia pada pasien kanker yang menerima radioterapi dan atau kemoterapi. Penelitian ini merupakan penelitian analitik observasional dengan desain cross-sectional. Metode pengambilan sampel dengan concecutive sampling dengan jumlah sampel minimal 47.Hasil penelitian menunjukan usia $p$-value $(0,321)>0,05$, jumlah fraksi $p$-value $(0,181)>0,05$, frekuensi sinar yang telah dijalani $p$-value $(0,160)>0,05$, jenis radioterapi $p$-value $(0,933)>0,05$, setting radioterapi $p$-value $(0,769)>0,05$, riwayat transfusi darah saat kemoterapi $p$-value $(0,411)>0,05$ dan asupan zat gizi (Protein $p$-value $(0,337)>0,05$, zat besi p-value $(0,086)>0,05$, zink $p$-value $(0,411)>0,05$, asam folat $p$-value $(0,963)>0,05$, vitamin $C$-value $(0,240)>0,05)$. Sedangkan dosis radiasi total yang diterima responden selama satu periode radioterapi menunjukan terdapat hubungan dengan kejadian anemia dengan nilai $p$-value $(0,045)<0,05$. Sehingga dapat disimpulkan tidak terdapat hubungan signifikan antara faktor usia, jenis kanker, jumlah fraksi, frekuensi sinar yang telah dilakukan, jenis radioterapi, seting radioterapi, riwayat transfusi darah dan asupan zat gizi. Sedangkan dosis total radiasi yang diberikan kepada responden menunjukan adanya hubungan signifikan dengan kejadian anemia.

\section{Corresponding Author:}

Alpha Olivia Hidayati

Program Studi D3 Radiologi, STIKES Guna Bangsa Yogyakarta, Indonesia

Email: alphaoliviahidayati@gmail.com 


\section{PENDAHULUAN}

Penyakit Kanker merupakan salah satu penyakit tidak menular yang menjadi pusat perhatian di dunia. Pada tahun 2017, diperkirakan hampir 9 juta orang meninggal di seluruh dunia akibat penyakit kanker, angka ini akan terus meningkat hingga 13 juta orang per tahun di 2030 (Rokom, 2017). Menurut data RISKESDAS 2013, prevalensi kanker di Indonesia mencapai 1,4 per 100 penduduk atau sekitar 347.000 orang. Prevalensi kanker tertinggi ditempati oleh kanker payudara yang mencapai 18,6\% (Aditya, 2013). Daerah Istimewa Yogyakarta menjadi provinsi dengan prevalensi penyakit kanker tertinggi yaitu 4,1 per 100 penduduk (Badan Penelitian dan Pengembangan Kesehatan Kemenkes RI, 2013).

Kanker adalah kondisi sel yang kehilangan kendali dalam mekanisme normalnya sehingga pertumbuhannya menjadi tidak normal dan cepat (Stephen, 2017). Sel Kanker mempunyai kemampuan menyusup ke jaringan di sekitarnya dan menyebar (metastasis) melalui pembuluh darah dan pembuluh getah bening (Greg, 2013). Berbagai upaya pengobatan kanker terus dikembangkan. Saat ini, pengobatan kanker dilakukan melalui operasi pengangkatan jaringan, radioterapi, dan atau kemoterapi (Nurjanah, 2016). Berdasarkan penelitian, radioterapi dapat menurunkan rekurensi kanker dalam 10 tahun dari 35\% menjadi 19,3\% pada kanker payudara (Wang, et.al., 2016). Salah satu parameter terjadinya malnutrisi pada pasien kanker adalah anemia (Maccio, et al., 2014; Aditya \& Gondhowiardjo, 2013).

Penelitian yang dilakukan pada 574 pasien (52\% perempuan) pada Desember 1996 dan Juni 1999 menunjukan bahwa $41 \%$ dari semua pasien mengalami anemia (hemoglobin $<12 \mathrm{~g} / \mathrm{dL}$ ) dan persentase ini meningkat menjadi $54 \%$ pada akhir terapi radiasi (Harrison, et al., 2001). Penelitian lain yang dilakukan di Belgia melaporkan, 79\% pasien dengan penyakit keganasan mengalami anemia, dan jumlah ini meningkat pada pasien yang mendapatkan kemoterapi, yaitu mencapai $90 \%$ pada pasien leukimia dan $69 \%$ pada tumor padat (Dicato, 2003). Hal ini didukung pula dengan penelitian yang dilakukan pada 60 tikus Wistar-Kyoto jantan yang diradiasi dengan sinar Gamma (kelompok pertama diradiasikan dengan lima dosis radiasi-Gamma, kelompok kedua 25 Gy; kelompok ketiga dengan 50 Gy, kelompok 4 dengan $100 \mathrm{~Gy}$, dan grup ke 5 adalah kontrol) menunjukkan bahwa terjadi penurunan sel darah merah, hemoglobin, dan hematokrit serta penghentian produksi eritrosit di sumsum tulang (Abdelhalim, 2015).
Anemia merupakan keadaan dimana jumlah eritrosit atau hemoglobin dalam darah berkurang sehingga tidak dapat menjalankan fungisnya dalam membawa $\mathrm{O}_{2}$ dalam jumlah cukup ke jaringan. Kekurangan oksigen pada pasien kanker yang mendapatkan radioterapi menyebabkan proses eradikasi sel kanker berjalan tidak efektif. Kemampuan radioterapi dalam eradikasi sel kanker sangat tergantung dengan kadar molekul oksigen dalam tumor. Oksigen merupakan radiosensitizer penting dalam penghancuran DNA sel kanker. Radioterapi membentuk radikal bebas dari molekul oksigen dan menerobos sampai DNA sel kanker sehingga menyebabkan sel kanker mati (Harrison, 2002; Spivak, et al., 2009; \& Andrew, et al., 2015). Selain kondisi di atas, anemia pada pasien kanker dapat menyebabkan kelelahan dan penurunan kualitas hidup dan meningkatnya mortalitas. Secara umum adanya anemia pada penderita kanker dapat meningkatkan mortalitas hingga $65 \%$. Anemia pada pasien karsinoma otak dan leher meningkatkan resiko kematian hingga 75\% sedangkan pada pasien limfoma mencapai 67\% (Rouli \& Pustika, 2005).

Berdasarkan hal tersebut, kejadian anemia pada pasien kanker menjadi penting untuk ditangani khususnya pada pasien yang menerima terapi. Untuk itu, penulis tertarik untuk meneliti faktor-faktor yang berhubungan dengan kejadian anemia pada pasien kanker yang menerima radioterapi dan atau kemoterapi, sehingga diharapkan dapat dilakukan penanganan anemia secara komprehensif berdasarkan etiologi penyakit.

\section{METODE}

Penelitian ini merupakan penelitian analitik observasional dengan desain crosssectional. Penelitian ini dilaksanakan pada bulan Maret-Oktober 2019 di Instalasi Radioterapi RSUP. Dr. Sardjito Yogyakarta.

Subjek penelitian adalah pasien kanker yang mendapatkan radioterapi dan atau kemoterapi pada bulan Mei-Agustus 2019 dengan perhitungan besar sampel minimal 47 pasien kanker yang memenuhi kriteria inklusi dan eksklusi. Metode pengambilan sampel dengan concecutive sampling. Kriteria inklusi yang ditetapkan untuk subyek antara lain pasien yang tidak merokok, umur pasien $<65$ tahun dan bersedia ikut penelitian dengan tanda tangan Informed Consent serta pasien dengan data rekam medis (usia, jenis kanker, stadium, dan riwayat terapi) yang lengkap. Sedangkan kriteria 
eksklusinya adalah pasien yang mengalami perdarahan dan pasien dengan hemofilia dan thalassemia.

Penelitian ini telah melewati kaji etik dan memperoleh Ethics Committee Approval dengan Nomor KE/FK/0548/EC/2019 oleh Medical and Health Research Ethics Committee (MHERC), Fakultas Kedokteran, Kesehatan Masyarakat, dan Keperawatan Universitas Gajah Mada Yogyakarta.

Variabel terikat yang diteliti adalah kejadian anemia yang terjadi pada pasien kanker yang menerima radioterapi dan atau kemoterapi. Variabel bebas yang diteliti adalah faktor-faktor yang dimungkinkan mempengaruhi terjadinya anemia pada pasien kanker. Pada penelitian ini faktor-faktor yang akan diteliti antara lain asupan zat gizi (protein, zat besi, zink, asam folat, dan Vitamin C), pemeriksaan hematologi (kadar hemoglobin, jumlah eritrosit dan hematokrit), riwayat kanker (jenis kanker dan stadium kanker), riwayat terapi kanker (dosis radiasi, frekuensi sinar yang telah dijalani, jumlah fraksi, status transfusi darah setelah kemoterapi, jenis radioterapi, dan setting radioterapi).

Teknik pengumpulan data yang dilakukan pada penelitian ini antara lain metode wawancara untuk memperoleh data asupan zat gizi (menggunakan semi quantitative-food frequency questionare/ SQ-FFQ ) yang hasil analisisnya dibandingkan dengan angka kecukupan gizI. Pengumpulan data sekunder dari data rekam medis pasien untuk memperoleh data usia, jenis kelamin, riwayat kanker, dan riwayat terapi. Pemeriksaan hematologi darah berupa pemeriksaan kadar hemoglobin, hematokrit dan jumlah eritrosit.

Data asupan zat gizi yang diperoleh dari wawancara menggunakan SQ-FFQ diolah dengan software nutrisurvey yang kemudian dibandingkan dengan nilai Angka Kecukupan Gizi (AKG). Data asupan zat gizi, riwayat kanker, riwayat terapi dan hasil pemeriksaan hematologi yang sudah diperoleh dilakukan analisis univariat dan bivariat.

\section{HASIL}

Penelitian yang dilaksanakan untuk melihat faktor-faktor yang berhubungan dengan kejadian anemia pada pasien kanker yang mendapatkan radioterapi dan kemoterapi adalah sebagai berikut.
Tabel 1. Distribusi Frekuensi Karakteristik Responden

\begin{tabular}{lrr}
\hline \multicolumn{1}{c}{ Variabel } & n & \% \\
\hline Jenis Kelamin & & \\
Perempuan & 45 & 90 \\
Laki - laki & 5 & 10 \\
Umur (th) & & \\
<46 & 13 & 26 \\
$46-54$ & 17 & 34 \\
$54-65$ & 20 & 40
\end{tabular}

Jenis Kanker

Kanker darah dan kanker

kelenjar getah bening

Kanker padat

$4 \quad 8$

Dosis Total (Gy)

$\geq 60$

$<60$

Frekuensi sinar yang telah dijalani

$\geq 18$

$<18$

Jumlah Fraksi

$\geq 25$

$<25$

$43 \quad 86$

$7 \quad 14$

Status Transfusi Darah setelah

Kemoterapi

Tidak Transfusi

Transfusi darah

$38 \quad 76$

Jenis Radioterapi

Internal dan eksternal $\quad 4 \quad 8$

Eksternal

$46 \quad 92$

Setting Radioterapi

Pasca Operasi

Sebelum Operasi

Status Anemia

Anemia

Tidak Anemia

24

48 52

Berdasarkan karakteristik responden terlihat bahwa sebagian besar responden penelitian berjenis kelamin perempuan $(90 \%)$ dan sisanya berjenis kelamin laki-laki (10\%). Umur responden dalam penelitian ini terbagi dalam tiga kelompok yaitu kurang dari 46 tahun sebanyak 26\%, kelompok umur 46-54 tahun sebanyak $34 \%$, dan kelompok umur 54-65 tahun sebanyak $40 \%$. Jenis kanker yang diderita oleh responden sebagian besar adalah kanker padat (92\%) yaitu kanker payudara, kanker servik dan kanker colon dengan stadium IIB-IIIB.

Dosis total yang diberikan kepada responden $66 \%$ mendapatkan dosis radiasi $\geq 60$ Gy sedangkan $40 \%$ responden mendapatkan dosis radiasi sebanyak <60 Gy. Frekuensi sinar yang telah dijalani oleh responden $48 \%$ telah menjalani lebih dari 18 kali penyinaran sedangkan 52\% telah menjalani kurang dari 18 kali penyinaran. Jumlah fraksi penyinaran yang 
harus dijalani responden selama satu periode terapi adalah $86 \%$ harus menjalani lebih dari 25 fraksi penyinaran dan $14 \%$ harus menjalani kurang dari 25 fraksi penyinaran. Pasien yang tidak menjalani transfusi darah pada saat kemoterapi mencapai $76 \%$ sedangkan sisanya harus menjalani transfusi darah pada saat menjalani kemoterapi. Jenis radioterapi yang diberikan kepada responden $92 \%$ menjalani radioterapi eksternal dan $8 \%$ menjalani radioterapi eksternal dan internal. Radioterapi yang dijalani responden setelah operasi sebanyak
86\% dan sisanya dilaksanakan sebelum atau tanpa operasi. Berdasarkan data yang diperoleh dapat diketahui pula bahwa $48 \%$ responden mengalami anemia dan $52 \%$ pasien tidak mengalami anemia selama menjalani radioterapi.

Selain data karakteristik responden, diperoleh pula data distribusi rata-rata jumlah eritrosit, hematokrit dan hemoglobin. Berdasarkan hal tersebut, diketahui jumlah eritrosit responden rata-rata $4,1650 \quad 10^{\wedge} 6 / \mu \mathrm{L}$ sedangkan hematokrit menunjukan rata-rata $36,4 \%$ dan hemoglobin $12,170 \mathrm{~g} / \mathrm{dL}$.

Tabel 2. Distribusi Rata-rata Hemoglobin, Jumlah Eritrosit dan Hematokrit

\begin{tabular}{|c|c|c|c|c|c|}
\hline Variabel & $\mathbf{n}$ & Mean & SD & $\begin{array}{l}\text { Minimum } \\
\text { Maximum }\end{array}$ & $95 \% \mathrm{CI}$ \\
\hline Jumlah Eritrosit & 50 & 41,650 & 0,50480 & $2,90-6,28$ & $3,6900-4,5770$ \\
\hline Jumlah Hemoglobin & 50 & 12,170 & 1,05 & $9.80-14,50$ & $10.80-13.58$ \\
\hline Jumlah Hematokrit & 50 & 36,396 & 463,152 & $13,20-42,50$ & $32,4300-40,4700$ \\
\hline
\end{tabular}

Tabel 3. Hubungan antara Karakteristik Subjek dengan Kejadian Anemia

\begin{tabular}{|c|c|c|c|c|c|c|c|}
\hline \multirow{3}{*}{ Variabel Independen } & \multicolumn{4}{|c|}{ Kejadian Anemia } & \multirow{2}{*}{\multicolumn{2}{|c|}{ Total $(n=50)$}} & \multirow{3}{*}{ p-value } \\
\hline & \multicolumn{2}{|c|}{ Anemia } & \multicolumn{2}{|c|}{ Tidak Anemia } & & & \\
\hline & n & $\%$ & n & $\%$ & $\mathbf{n}$ & $\%$ & \\
\hline \multicolumn{8}{|l|}{ Usia (th) } \\
\hline$<46$ & 6 & 46,2 & 7 & 53,8 & 13 & 100 & \multirow{3}{*}{0,321} \\
\hline $46-54$ & 6 & 35,3 & 11 & 64,7 & 17 & 100 & \\
\hline $54-65$ & 12 & 60,0 & 8 & 40,0 & 8 & 100 & \\
\hline \multicolumn{8}{|l|}{ Jenis Kanker } \\
\hline $\begin{array}{l}\text { Kanker darah dan kanker } \\
\text { kelenjar getah bening }\end{array}$ & 2 & 50,0 & 2 & 50,0 & 4 & 100 & \multirow[t]{2}{*}{0,933} \\
\hline Kanker padat & 22 & 47.8 & 24 & 52,2 & 46 & 100 & \\
\hline \multicolumn{8}{|l|}{ Jumlah Fraksi } \\
\hline$\geq 25$ & 19 & 44,2 & 24 & 55,8 & 43 & 100 & \multirow{2}{*}{0,181} \\
\hline$<25$ & 5 & 71,4 & 2 & 28,6 & 7 & 100 & \\
\hline \multicolumn{8}{|l|}{ Dosis Total (Gy) } \\
\hline$\geq 60$ & 19 & 57,6 & 14 & 42,4 & 33 & 100 & \multirow{2}{*}{$0,045^{*}$} \\
\hline$<60$ & 5 & 29,4 & 12 & 70,6 & 17 & 100 & \\
\hline \multicolumn{8}{|l|}{$\begin{array}{l}\text { Frekuensi sinar yang telah } \\
\text { dijalani }\end{array}$} \\
\hline$\geq 18$ & 14 & 58,3 & 10 & 41,7 & 24 & 100 & \multirow{2}{*}{0,160} \\
\hline$<18$ & 10 & 38,5 & 16 & 61,5 & 26 & 100 & \\
\hline \multicolumn{8}{|l|}{ Jenis Radioterapi } \\
\hline Internal dan eksternal & 2 & 50 & 2 & 50 & 4 & 100 & \multirow{2}{*}{0,933} \\
\hline Eksternal & 22 & 47,8 & 24 & 52,2 & 46 & 100 & \\
\hline \multicolumn{8}{|l|}{ Setting Radioterapi } \\
\hline Pasca Bedah & 21 & 48,8 & 22 & 51,2 & 43 & 100 & \multirow{2}{*}{0,769} \\
\hline Sebelum Bedah & 3 & 42,9 & 4 & 57,1 & 7 & 100 & \\
\hline \multicolumn{8}{|l|}{$\begin{array}{l}\text { Riwayat Transfusi Darah saat } \\
\text { Kemoterapi }\end{array}$} \\
\hline Tidak Transfusi & 17 & 44,7 & 21 & 55,3 & 38 & 100 & \multirow{2}{*}{0,411} \\
\hline Transfusi darah & 7 & 58,3 & 5 & 41,7 & 12 & 100 & \\
\hline
\end{tabular}


Tabel 4. Distribusi Rata-rata Asupan Zat Gizi

\begin{tabular}{lcrrrrr}
\hline \multicolumn{1}{c}{ Variabel } & $\mathbf{n} \begin{array}{c}\text { Nilai rekomendasi } \\
\text { /hari berdasar } \\
\text { AKG }\end{array}$ & Mean & SD & \multicolumn{1}{c}{$\begin{array}{l}\text { Minimum } \\
\text { Maximum }\end{array}$} & \multicolumn{1}{c}{ 95\% CI } \\
\hline Protein & 50 & $60,1 \mathrm{~g}$ & 102,75 & 4,49 & $59,20-94,10$ & $64,7-143,61$ \\
Zat besi & 50 & $12,5 \mathrm{mg}$ & 30,47 & 8,38 & $6,130-45,60$ & $21,38-40,61$ \\
Zinc & 50 & $11,6 \mathrm{mg}$ & 11,39 & 11,10 & $4,10-20,20$ & $6,80-16,39$ \\
Asam Folat & 50 & $400 \mathrm{mg}$ & 575,84 & 233,06 & $120,70-966,10$ & $286,25-903,78$ \\
Vitamin C & 50 & $100 \mathrm{mg}$ & 408,73 & 202,94 & $40,80-85,80$ & $127,90-639,00$ \\
\hline
\end{tabular}

Usia responden menunjukan tidak terdapat hubungan dengan kejadian anemia. Hal ini terlihat dari nilai $p$-value $(0,321)>0,05$. Demikian pula pada pada jenis kanker ( $p$-value $=0,933)$, jumlah fraksi $(p$-value $=0,181)$, frekuensi sinar yang telah dijalani $(p$-value $=0,160)$, jenis radioterapi ( $p$-value $=0,933)$, setting radioterapi ( $p$-value $=0,769)$ dan riwayat transfusi darah saat kemoterapi ( $p$-value $=0,411)$. Namun demikian, dosis radiasi total yang diterima responden selama satu periode radioterapi menunjukan terdapat hubungan dengan kejadian anemia dengan nilai $p$-value $(0,045)<0,05$.
Berdasarkan asupan zat gizi responden terlihat bahwa rata-rata asupan zat gizi responden telah memenuhi nilai rekomendasi per hari berdasarkan AKG (Angka Kecukupan Gizi). Hal ini terjadi pada kadar protein, zat besi, zinc, asam folat dan Vitamin C. Hasil analisis statistik menunjukan bahwa tidak terdapat hubungan antara asupan zat gizi (protein ( $p$-value $=0,337)$, zat besi ( $p$-value $=0,086)$, Zink ( $p$-value $=0,411)$, asam folat $(p$-value $=0,963)$ dan vitamin $\mathrm{C}(p$ value $=0,240)$ dengan kejadian anemia pada pasien kanker yang mendapatkan radioterapi dan atau kemoterpi ( $p$-value $>0,05)$.

Tabel 5. Hubungan antara Asupan Zat Gizi dengan Kejadian Anemia

\begin{tabular}{|c|c|c|c|c|c|c|c|}
\hline \multirow{3}{*}{ Variabel Independen } & \multicolumn{4}{|c|}{ Status Anemia } & \multirow{2}{*}{\multicolumn{2}{|c|}{ Total $(n=50)$}} & \multirow{3}{*}{ p-value } \\
\hline & \multicolumn{2}{|c|}{ Anemia } & \multicolumn{2}{|c|}{ Tidak Anemia } & & & \\
\hline & n & $\%$ & n & $\%$ & $\mathbf{n}$ & $\%$ & \\
\hline \multicolumn{8}{|l|}{ Protein $(\mathrm{g})$} \\
\hline$<60.1$ & 1 & 25,0 & 3 & 75,0 & 4 & 100 & \multirow{2}{*}{0,337} \\
\hline$\geq 60.1$ & 23 & 50,0 & 23 & 50,0 & 46 & 100 & \\
\hline \multicolumn{8}{|l|}{ Zat Besi (mg) } \\
\hline$<12,5$ & 0 & 0 & 3 & 100 & 3 & 100 & \multirow{2}{*}{0,086} \\
\hline$\geq 12,5$ & 24 & 51,1 & 23 & 48,9 & 47 & 100 & \\
\hline \multicolumn{8}{|l|}{ Zink (mg) } \\
\hline$<11,6$ & 7 & 58,3 & 5 & 41,7 & 12 & 100 & \multirow{2}{*}{0,411} \\
\hline$\geq 11,6$ & 17 & 44,7 & 21 & 55,3 & 38 & 100 & \\
\hline \multicolumn{8}{|l|}{ Asam Folat (mg) } \\
\hline$<400$ & 10 & 47,6 & 11 & 52,4 & 21 & 100 & \multirow{2}{*}{0,963} \\
\hline$\geq 400$ & 14 & 48,3 & 15 & 51,7 & 29 & 100 & \\
\hline \multicolumn{8}{|l|}{ Vitamin C (mg) } \\
\hline$<100$ & 7 & 63,6 & 4 & 36,4 & 11 & 100 & \multirow{2}{*}{0,240} \\
\hline$\geq 100$ & 17 & 43,6 & 22 & 56,4 & 39 & 100 & \\
\hline
\end{tabular}

\section{PEMBAHASAN}

\section{Umur}

Berdasarkan penelitian ini, diperoleh hasil penelitian yang menunjukan sebagian besar responden adalah perempuan yang berumur 5465 tahun dengan tingkat kejadian anemia yang lebih tinggi dibandingkan pada kelompok umur yang lain. Namun demikian secara statistik tidak terdapat hubungan antara umur dan kejadian anemia. Hal ini sejalan dengan penelitian yang dilakukan oleh Priyanto (2018). Kejadian anemia pada usia pra lansia dapat terjadi karena sindrom gagal sumsum tulang, penurunan produksi eritropoietin pada ginjal, defisiensi nutrisi hingga proses terjadinya inflamasi (Stauder, et al., 2018).

Resiko penyakit kanker payudara meningkat seiring dengan bertambahnya usia (Nani, 2009). Hal ini terkait dengan mulai menurunnya metabolisme tubuh seiring dengan bertambahnya usia dan ditambah lagi dengan radioterapi yang diterima oleh pasien berakibat pada rusaknya eritrosit yang berdampak pada penurunan kadar hemoglobin. Kondisi ini 
meyebabkan terjadinya anemia (Maccio, et al., 2014; Aditya \& Gondhowiardjo, 2013). Anemia pada pasien kanker menyebabkan proses pengobatan kanker menjadi tidak optimal dikarenakan oksigen yang berperan sebagai radiosensitizer dalam penghancuran DNA sel kanker tidak dapat bekerja maksimal (Harrison, 2002; Andrew, et al., 2015).

\section{Karakteristik Hasil Pemeriksaan Hematologi}

Berdasarkan rata-rata hemoglobin, jumlah eritrosit dan hematokrit terlihat bahwa nilai ketiganya mendekati ambang bawah standar dan ketiganya secara statistik tidak menunjukkan terdapat hubungan yang signifikan. Pada hemoglobin seseorang dikatakan anemia jika hemoglobin $<12 \mathrm{~g} / \mathrm{dL}$. Sedangkan jumlah eritrosit mempunyai standar $4,00-5,40 \quad 10^{\wedge} 6 / \mu \mathrm{L}$. Hematokrit mempunyai standar 35-49\%. Kondisi ini menujukan bahwa tubuh responden mampu mempertahankan kondisi walaupun radioterapi yang diberikan menyebabkan kerusakan eritrosit (Wang, et.al, 2016). Tubuh dapat mempertahankan kondisinya jika didukung oleh nutrisi yang cukup. Hal ini terlihat dari rata-rata asupan zat gizi yang sesuai dengan nilai rekomendasi per hari berdasarkan nilai $\mathrm{AKG}$ (angka kecukupan gizi). Tingkat asupan zat gizi yang cukup seperti protein, zat besi, vitamin $\mathrm{B}_{12}$, asam folat dan vitamin $\mathrm{C}$ dapat mencegah terjadinya anemia (Alamsyah \& Dini, 2016).

\section{Riwayat Kanker}

Riwayat kanker yang diteliti dalam penelitian ini antara lain jenis kanker dan stadium kanker. Sebanyak 92\% responden menderita kanker padat dengan stadium IIB-IIIB. Jenis kanker yang sebagian besar diderita oleh responden adalah kanker payudara. Berdasarkan kejadian anemia dapat diketahui bahwa tidak terdapat hubungan antara jenis kanker dengan kejadian anemia. Malnutrisi khususnya anemia yang terjadi pada pasien kanker terjadi karena radioterapi yang diberikan pada daerah abdomen dan pelvis berakibat gastritis dan entritis yang pada akhirnya menyebabkan ulserasi dan obstruksi (Gallagber, et.al., 2012).

Gastritis merupakan peradangan
(inflamasi) dari mukosa lambung yang
disebabkan oleh faktor iritasi dan infeksi.
Sedangkan entritis adalah radang selaput lendir
saluran pencernaan yang ditandai dengan muntah
dan diare (Saydam, 2011). Kondisi ini
menyebabkan pasien kekurangan nutrisi
dikarenakan turunnya nafsu makan sehingga

memungkinkan terjadinya anemia. Sedangkan pada penelitian ini, sebagian besar pasien menderita kanker payudara yang mendapatkan radioterapi di daerah thorak, sehingga gastritis dan entritis kecil terjadi. Hal ini dibuktikan dari hasil wawancara dengan responden yang menyatakan bahwa $80 \%$ responden tidak mengalami mukositas, $62 \%$ responden tidak mengalami penurunan nafsu makan, $70 \%$ responden tidak mengalami mual muntah dan $66 \%$ responden tidak mengalami perubahan sensasi rasa makanan.

\section{Riwayat Terapi Kanker}

Penelitian ini juga menunjukkan bahwa tidak terdapat hubungan antara variabel jumlah fraksi, frekuensi sinar yang telah dijalani, jenis radioterapi, setting radioterapi dan riwayat transfusi darah saat kemoterapi dengan kejadian anemia. Hal ini sejalan dengan penelitian Nurjanah, dkk (2016) yang menunjukkan tidak terdapat hubungan yang signifikan antara kejadian anemia dengan jumlah fraksi radioterapi. Pada metode fraksinasi konvensional, terapi radiasi dilakukan dengan frekuensi 5 kali dalam satu minggu, dengan dosis perfraksi berkisar 1,8-2Gy untuk dosis total 50-6-Gy. Dengan metode ini sel diberikan kesempatan untuk melakukan perbaikan akibat radiasi yang diterima (Susworo, 2007).

Secara statistik dosis radiasi total yang diterima oleh pasien mempunyai hubungan dengan kejadian anemia pada pasien kanker yang mendapatkan radioterapi dan atau kemoterapi. Hal ini sejalan dengan penelitian Harrison (2001) yang menunjukkan adanya kejadian anemia pada pasien yang mendapatkan radioterapi. Hal ini dapat terjadi karena adanya penurunan jumlah eritrosit dan hematokrit yang disebabkan oleh terganggunya produksi eritrosit pada sumsum tulang (Nurjanah dkk, 2016; Abdelhalim, et al., 2015). Penelitian lain yang dilakukan di Belgia melaporkan, $79 \%$ pasien dengan penyakit keganasan mengalami anemia, dan jumlah ini meningkat pada pasien yang mendapatkan kemoterapi, yaitu mencapai $90 \%$ pada pasien leukimia dan 69\% pada tumor padat (Dicato, 2003).

\section{Asupan Zat Gizi}

Asupan zat gizi tidak menunjukan adanya hubungan dengan kejadian anemia pada pasien kanker yang mendapatkan radioterapi dan atau kemoterapi. Asupan zat gizi yang cukup dimungkinkan hanya mampu mempertahankan 
kadar hemoglobin dan eritrosit pasien kanker, namun tidak mampu meningkatkan kadar hemoglobin dan jumlah eritrosit. Hal ini dikarenakan radioterapi yang masih diterima bersifat merusak eritrosit. Namun demikian dengan pemberian metode fraksi memberikan kesempatan kepada tubuh untuk melakukan perbaikan sel-sel yang rusak akibat radioterapi. Dalam hal ini, pemberian zat gizi yang cukup dapat membantu proses perbaikan yang dilakukan oleh sel (Alamsyah \& Dini, 2016)

Dari hasil penelitian terlihat bahwa asupan protein, zat besi, zink asam folat dan vitamin $\mathrm{C}$ memenuhi angka kecukupan gizi (AKG). Protein di dalam tubuh berfungsi dalam perbaikan sel-sel yang rusak sehingga dengan kecukupan protein di dalam tubuh dapat memperbaiki kondisi susmsum tulang yang mengalami kerusakan karena radioterapi. Selain itu, protein juga berfungsi dalam transportasi dan penyimpanan besi karena aktifitas redoks besi. Zat besi merupakan mikronutrien essensial untuk sintesis hemoglobin dalam eritrosit dan mioglobulin dalam otot. Kekurangan zat besi dapat berakibat terganggunya sintesis hemoglobin. Zink

\section{DAFTAR PUSTAKA}

Abdelhalim MA, Al-Ayed MS, Moussa SA, \& Abd Al-Sheri Ael-H. (2015). The effects of gamma-radiation on red blood cell corpuscles and dimensional properties in rats. Pak $J$ Pharm Sci. Sep;28(5 Suppl):1819-22.

Aditya E, \& Gondhowiardjo SA. (2013). Hipofraksinasi pada kanker payudara stadium dini. Radioterapi dan Onkologi Indonesia. Vol. 4(2):53-60.

Alamsyah PR \& Dini RA. (2016). Hubungan Kecukupan Zat Gizi dan Konsumsi Makanan penghambat Zat Besi dengan Kejadian Anemia pada Lansia. Media Gizi Indonesia. Vol 11(1). Hal: 48-54.

Andrew J, Bishop MD, Pamela KA, Larissa AM, Meyer MD, \& Patricia JE. (2015). Relationship betwen low hemoglobin levels and outcames after treatment with radiation or chemoradiation in patients with cervical cancer: has the impact of anemia been overstated? International Journal of Radiation Oncology, Biology, Phisics. Vol 91(1); PP196-205.

Badan Penelitian dan Pengembangan Kesehatan Kemenkes RI. (2013). Riset Kesehatan Dasar (RISKESDAS) 2013. Badan berfungsi dalam pembentukan senyawa ala dehidratase yang berperan dalam sintesis heme (Gropper, et al., 2009). Asam folat berperan sebagai ko-enzim metabolisme asam amino glycine yang berperan dalam pembentukan heme. Vitamin $\mathrm{C}$ berperan sebagai promotor absorpsi besi dengan cara mereduksi besi ferri menjadi ferro sehingga zat besi dapat digunakan oleh tubuh (Saptyasih, 2016).

\section{SIMPULAN}

Penelitian ini menunjukan tidak terdapat hubungan antara faktor usia, jenis kanker, jumlah fraksi, frekuensi sinar yang telah dilakukan, jenis radioterapi, seting radioterapi, riwayat transfusi darah dan asupan zat gizi terhadap kejadian anemia pada pasien yang mendapat radioterapi dan kemoterapi. Sedangkan dosis radiasi total yang diterima pasien selama satu periode radioterapi menunjukan adanya hubungan dengan kejadian anemia pada pasien yang mendapat radioterapi dan kemoterapi.

Penelitian dan Pengembangan Kesehatan Kemenkes RI. Hal: 85-86.

Dicato M. (2003). Anemia in cancer:some phatophysiologi aspects. Oncologist. Vol. 8 (1) PP:19-21.

Gallagber M. (2012). The Nutrients and Their Metabolism in: Krause's Food and Nutrition Theraphy. $13^{\text {th }}$ ed. Missauri: Elsevier Inc. PP: 118-136.

Greg A. (2013). Cancer: 50 essential thing to do. Ed 4th. Plame. USA.

Gropper S, Smith J,\& Groff J. (2009). Microminerals; In: Advance Nutrition and Human Metabolism. $5^{\text {th }}$. CanadaWadsworth Cengage Learning. P: 376, 476, 477, 480, 483.

Harrison L, Daniel S, Lauren S, Carol W B, \& Ramden Russel. (2001). Prevalence of anemia in cancer patients undergoing radiation therapy. Seminars in Oncology. Vol 28(2) (Suppl 8) PP:54-59.

Harrison LB. (2002). Impact of tumor hypoxia and anemia on radiation therapy outcames. Oncologist. Vol:7. PP: 492-508.

Maccio A, Clelia G, Carlo M, Luciana T, Maria CC, Carlo F, Itaru O, Antonio B \& Tomas G. (2014). The role of inflamation, iron and nutritional status in cancer-related 
anemia: results of a large prospective observational study. Jorunal of Haematologica. Published Ahead of Print. On September $19 . \quad$ doi: 10.3324/haematol.2014.112813.

Nani D. (2009). Hubungan Umur Awal Menopouse dan Status Penggunaan Kontrasepsi hormonaldengan Kejadian Kanker Payudara. Jurnal Keperawatan Soedirman. Vol. 4(3). Hal: 102-106.

Nurjanah A,Etika R N, Niken, P, \& Ahmad S. (2016). Hubungan jumlah fraksi radioterapi dengan kadar hemoglobin pasien kanker serviks di RSUP DR Kariadi. Journal of Nutrition College. Vol. 5(1). Hal: 1-7.

Priyanto LD. (2018). Hubungan Umur, Tingkat Pendidikan, dan Aktivitas Fisik Santriwati Husada dengan Anemia. Jurnal Berkala Epidemiologi. Vol. 6(2). Hal:139-146.

Rokom. (2017). Kementrian kesehatan ajak masyarakat cegah dan kendalikan kanker. http://sehatnegeriku.kemkes.go.id/baca/rili s-media/20170202/2119525/kementeriankesehatan-ajak-masyarakat-cegah-dankendalikan-kanker/

Rouli N \& Pustika A. (2005). Anemia pada penyakit keganasan anak. Sari Pediatri. Vol. 6(4). Hal: 176-181.

Spivak JL, Gascon P \& Ludwig H. (2009). Anemia management in oncology and hematology. Oncologist. 14(Suppl 1). PP: 43-56.

Saptyasih AR, Laksmi W, \& Nugraheni. (2016). Hubungan Asupan Zat Besi, Asam Folat, Vitamin B12, dan Vitamin C dengan Kadar Hemoglobin Siswa di SMP Negeri 2 Tawangharjo Kabupaten Grobogan. Jurnal Kesehatan Masyarakat. Vol. 4(4). Hal: 521-528.

Saydam. (2011). Memahami Berbagai Penyakit (Penyakit Pernapasan dan Gangguan Pencernaan). Bandung: Alfabeta.

Stauder, R., Valent, P., \& Theurl, I. (2018). Anemia at older age: etiologies, clinical implications, and management. Blood, The Journal of the American Society of Hematology, 131(5), 505-514.

Stephen AR. (2017). Cancer: What You Need to Know. Stephen Rosenberg MD.LLC. Madison.PP :1-137.

Susworo R. (2007). Radioterapi. Dasar - Dasar Radioterapi. Tata Laksana Radioterapi Penyakit Kanker. Jakarta: Universitas Indonesia.

Wang Q, Ye T, Chen HL, Zhang XG, \& Zhang LZ. (2016). Correlation between intensity modulated radiotherapy and bone marrow suppression in breast cancer. European Review for Medical and Pharmacological Sciences. Vol. 20.PP:75-81. 